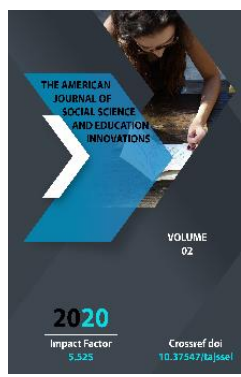

\title{
The Issues Of Structural Categories Of Nominative
} Sentences

Ergashev Muhammadjon Rakhmonovich, PhD In Philological Sciences, Lecturer Of Kokand State Pedagogical Institute, Kokand, Uzbekistan

\section{ABSTRACT}

Traditional nominative sentences are one-syllable compounds, which represent the present tense and have real modal meanings. There are different opinions about its structural - semantic and communicative structure. The structure of the nominative constructions remains problematic. This article discusses the issue of structural categories of nominative sentences.

\section{KEYWORDS}

Sentences, nominative sentences, structural - semantic categories, nominative constructions,

\section{INTRODUCTION}

Traditional nominative sentences are onesyllable compounds, which represent the present tense and have real modal meanings. There are different opinions about its structural - semantic and communicative structure. The structure of the nominative constructions remains problematic. There is neither a clear definition nor the role of nominative sentences in the language system which includes a set of specific features has been resolved. 


\section{MATERIALS AND METHODS}

The scholars who investigated on traditional syntax such as G.F. Nizyayeva, and L.N. Sanjarov consider the nominative sentence as a predicate represented by a noun and a broad secondary part. There are two approaches to nominative sentences: broad and narrow. The narrow approach was formed in the XIX century, and A.A. Potebnya, A.M. Peshkovsky, AA Shakhmatov made a significant contribution to its development. There are strict requirements for this approach, which include:

$>$ Absence of verbs in nominative sentences;

$>$ Absence of complement and case in nominative sentences (can be a determiner expressed by an adjective or a noun);

$>$ Nominative sentences should be in the affirmative form only;

$>$ Nominative sentences are only adverbs;

The analysis and in-depth study of nominative sentences were begun in the 50 s of the last century. V.V Vinogradov's contribution to this process was significant. For example, in the analysis of the words "Tun", "Tun edi", "Tun bo ladi" ("Night", "It was night", "It will be night") in the following two examples which represents "Time" according to its content, although in the next two senses the verbs are present. They all have one main part, they all have the conjunction "to be", and only in the first example it is in the form of a case. Gradually, the ideas have emerged that the nominative can be a case or a complement and can be in the form of affirmation or negative. As a result, a broad approach to nominative speech has emerged in linguistics. According to this approach, the main part of a nominative sentence is represented by a noun in the general agreement, and it contains the following:

$>$ Amount - a combination of a noun (I have three rubles);

$>$ The use of noun in the accusative case in such expressions as "more", "less", "around", "about": It was past midnight; He had about 20,000 soums.

$>$ In the Russian language with the preposition (по) in the expression of division which is interpreted with the suffix -tadan in Uzbek; В руках у него по два котенка. Uning qo'llarida ikkitadan mushukcha bor edi. (She had two kittens in her arms)

$>$ In some cases, instead of a noun in the general agreement, there are nonindependent statements: Va yana bayram, va yana uylar uzra "Yangi yilingiz bilan". (And it is a holiday again in the houses, Happy New Year one more time).

As for the problem of verbs in nominative sentences, they use connecting verbs such as "bo'lish" (to be), "yotib kelish" (to stay), "qolish" (to become), "bo'lib qolish" (to become, to remain) and the connecting verb "to be" has its own case in the present tense. Nominative sentences, nominal sentences are the sentences with a simple main part, without a verb, with a main part represented by a noun. In nominative sentences, the presence of something or an event is reported. "Izg irinli tun" (chilly night), "ochiq, sokin kunlar" (bright, quiet days) nominative sentences often come with pronouns: "Mana tegirmon" (Here is the mill). Nominative sentences include titles of books by some authors, as well as store names: "War and Peace" (Urush va tinchlik), "Supermarket Tarona" (Supermarket Tarona). 
Nominative expressions are especially widely used in fiction and poetry. Nominative sentences are widely used in fiction to describe things and events in an artistic and figurative way. Nominative sentences are not widely used in everyday speech, but they are also widely used in oral speech in the sense of existence. From a stylistic point of view, nominative sentences are very convenient and can evoke emotionality. Nominative words can mean something or a sign: Samarqand - go'zal shahar. Butunlay tarixiy madrasalar, masjidlar, minoralar (Samarkand is a beautiful city. Completely historic madrasah, mosques and minarets are there).

Nominative sentences can come before or after a sentence to explain a sentence, and these are called prepositive and postpositive terms. In nominative clauses, the noun in the main clause acts as the possessive and in some cases the nouns used with the pronouns and the demonstrative pronoun also act as possessives.

Nominative sentences can clearly express their function in the context of the thing or event they are explaining. Nominative sentences can be explained by the notions expressed in the general agreement and they precede the thing or event they are directly interpreting, in which case they logically reinforce the reader's thoughts and attention: : His-tuyg u. Bu olimlarning diqqat markazidagi muammo. (Emotion. This is an issue which attracts attention of the scientists).

\section{RESULTS AND DISCUSSIONS}

As we are investigating the nominative sentences, we also come across the singular nominative sentences. These are the words and phrases in the general agreement which have no idiomatic forms, source of existence and complete intention and communicative function.

Individual nominatives are part of syntactic combinations and are connected with them in a logical and intonational connection. Although individual nominatives cannot existed independently and can be a component of the text in two ways. Individual nominative speech is widely used in speech. They play an important role in emphatic intonation and location. Nominative sentences are similar in form to some syntactic devices. The difference between these syntactic devices and nominative sentences is that they have no meaning of existence and cannot be used independently. They sometimes exist as an inaccurate form of two-part clauses and are considered members of the main clause.

Nominative sentences can be followed by a number of other nominative sentences after them and gives meaning to the endless chain of memories. At the end of the sentence, the present participle is rich in emotional and semantic possibilities. Such a syntactic priome which represents an emotional mood:

Og'ir va bo'm bosh. O'lik tun. Tamaki kuli, qayg'u. (Heavy and empty. Dead night. Tobacco ash, grief)

When a nominative sentence precedes the sentence to which it is connected, it signifies an assessment of something or an event: Xat bor, Varoqda shoshilinch satrlar! Agar kechira olsang -kechir. Shunday bo lib qoldi. Kettim! (There is a letter, there are hasty lines on the page! If you can, forgive me. That's what happened. I'm gone!) 
Nominative sentences are also widely used in popular science articles. For example: Obozidan tez uchuvchi laynerlari. Murakkab texnologik jarayonlarni boshqaruvchi, elektron miya. (Flying supersonic liners. The electronic brain, which controls complex technological processes).

The nominative expresses the sign of an object and names the different details of the previous message: Irkutsk - alo shahar, butunlay o'qimishli. Teatr, muzey, shahar bog`l va yaxshi mexmonxonalar. (Irkutsk is an excellent city, completely educated. Theater, museum, a city park and good hotels are there.)

Although the formal-grammatical structure of nominative sentences has a rigid structure, they are functionally very diverse. This ambiguity leads to different interpretations of nominative sentences.

There are different views among linguists on the testing of nominative sentences. According to the scholars such as A.A. Potebiya, F.F. Fortunatov, A.M. Peshkovsky, nominative sentences are considered as predicative of main sentences. The scientists D.N. ObsyanikoKulikovsky and V.A. Bogoroditsky believe that the basis of nominative sentences is the owner of the sentence. A.A. Shakhmatov and E.M. Galkin-Fidoruk consider that nominative sentences are the subject and predicative. Even those who do not consider this issue at all on the main issue of nominative statements are controversial. There is also various controversy over the boundary of the class of nominative sentences. The point is that there are debates as to which nominative constructions are to be considered as sentences, which ones are not to be considered as sentences, and there are differences of opinion as to whether there are one-syllable and two-syllable forms of similar forms. The objective reason for these views depends on the semantic and functional volume of nominative sentences. In particular, it is very difficult to distinguish nominative sentences from similar devices. Titles, inscriptions on the counters, words that express the image expressed in the general agreement, for example: Quvonch... qanday qilib uni ko 'ksinga sig'dirasan., avval aytilgan fikrga baxo berish; Vaqt juda Reputatsiyalar, gostrollar. (Joy... how to feel it in the heart.., to evaluate the previously expressed idea; Time is very Reputations, tours). Nominative sentence for introducing a person: Mehmon qo 'lini cho'zdi - Ivanov? (The guest is going to greet - Ivanov?). In some cases, these syntactic phenomena are considered to be speech, and some scholars believe that these sentences are beyond the scope of simple speech. There are also different opinions about nominative speech. The main factor in the limitation of nominative sentences and similar constructions is in a logical function. This approach makes it possible to distinguish nominative sentences from similar constructions, i.e they are not identified (or interpreted) by various constructions.

\section{CONCLUSION}

In conclusion we can say that nominative sentences have not yet been resolved in modern linguistics and we have to carry more researches on the issues of structural categories of nominative sentences. 


\section{REFERENCES}

1. I.Rasulov. One-syllable sentences in modern Uzbek literary language. Monograph. T.1978.

2. G.Abdurahmonov, Sh.Shukurov, Q.Mahmudov. Historical grammar of the Uzbek language. T.2009.

3. Babaytseva V.V. The system of one-part sentences in modern Russian. $M$.: Bustard, 2004.

4. Sh.Rahmatullaev. Modern Uzbek literary language.T.2012.

5. Sarimsakova,D.(2017).Station Rotation. English Teaching Professional, 109.

6. Sarimsakova, D. M. (2020). SOCIOLINGUISTIC COMPETENCE AND COMMON REFERENCE LEVELS OF THE CEFR. In МИРОВАЯ ЭКОНОМИКА. ПРОБЛЕМЫ, ПЕРСПЕКТИВЫ, ИННОВАЦИИ (рp. 4-6). 